\title{
New Records of Algae in Shaqlawa District, Erbil, Kurdistan Region of Iraq
}

\author{
Janan J. Toma* and Farhad H. Aziz \\ Department of Environmental Sciences and Health, College of Science, \\ Salahaddin University-Erbil, Kurdistan Region-Iraq
}

\begin{tabular}{|c|c|}
\hline Article's Information & Abstract \\
\hline $\begin{array}{l}\text { Received: } \\
\text { 14.08.2021 } \\
\text { Accepted: } \\
\text { 10.09.2021 } \\
\text { Published: } \\
\text { 30.09.2021 }\end{array}$ & $\begin{array}{l}\text { Monthly samples of algae collected in eighteen sites of springs and streams } \\
\text { through September-2019 till August-2020during morning till afternoon in } \\
\text { Shaqlawa district within Erbil Province, Kurdistan Region of Iraq. Eleven various } \\
\text { kinds of algae were identified for first time in Iraqi inland water, distributed to } \\
\text { three genera of blue-green algae, which include Marssoniella elegans, } \\
\text { Pseudoanabaena catenata, Cyanotheca aeroginosa, also in Pyrrophyta identified } \\
\text { four new species genera include Gvmnodium inversum. Woloszvnskia tenuissima, }\end{array}$ \\
\hline $\begin{array}{l}\text { Keywords: } \\
\text { New } \\
\text { Records } \\
\text { Algae } \\
\text { Shaqlawa } \\
\text { Erbil } \\
\text { Kurdistan } \\
\text { Iraq }\end{array}$ & $\begin{array}{l}\text { Peridinium goslaviense, Hemidinium naustum and Xanthopyta recorded three } \\
\text { species were Ophiocytium arbuscula, Ophiocytium parvulum, Tetraedriella } \\
\text { polychloris while Cryptophyta only have one species was Cryptomonas reflex. } \\
\text { According to physicals and chemicals characteristics, water temperature varied } \\
\text { from } 14.942{ }^{\circ} \mathrm{C} \text { to } 18.475{ }^{\circ} \mathrm{C} \text {, pH lies on alkaline side of neutrality, electrical } \\
\text { conductivity ranged between }(627.472-2092.306 \mu \mathrm{s} / \mathrm{cm}) \text { and high concentration of } \\
\text { salinity recorded in Azarian spring, higher value of calcium and magnesium } \\
\text { recorded in Azarian and Benwan springs were } 294.84 \mathrm{mg} / \mathrm{L} \text { and } 106.578 \mathrm{mg} / \mathrm{L} \\
\text { respectively. Lower value of nitrate and phosphate reported in Sard and Piawan } \\
\text { springs, while lower value of sulfate observed in Prenga spring. }\end{array}$ \\
\hline
\end{tabular}

DOI: $10.22401 /$ ANJS.24.3.09

*Corresponding author: janan.toma@su.edu.krd

\section{Introduction}

Algae are base of food chain and primary producer in aquatic environment, also they have a great role for water purification and water quality assessment because these organisms are sensitive to any changes in inland water and reflect healthy status of any water ecosystem, therefore they used to indicate quality of water and pollution status in any water ecosystem [1]. Algae abundant in different areas and habitat some of these are cosmopolitan in distribution and found in various parts of the world's [2]. Microalgae are photoautotrophic, and they have bioactive, antibacterial and antioxidant compounds or considered sources of food, clean energy and plant fertilizer [3]. Variation of algae in water ecosystem depended on the changes of the environmental factors [4]. More recently algal studies in Kurdistan region of Iraq get attentions, there are many studies occurred on algal flora, a total 1341 algal flora was records in the check list Kurdistan Region of Iraq by[5], also list of Algae in Iraq contains 2647 taxa by [6]. Furthermore, many of studies recently published in Kurdistan Region and Iraq may do by $[1,4,7-11]$. The purposes of the current study are to know composition of non-diatoms algae in Shaqlawa district within Erbil Province and contribution to algae in Iraq and Kurdistan Region of Iraq.

\section{Materials and Methods}

\subsection{Description of studied sites}

Aquban and Sarkand villages belong to Shaqlawa District is about $32 \mathrm{Km}$ northeast of Erbil city which is located northeast of Iraq, at $36^{\circ} 42^{\prime}$ to $36^{\circ} 23^{\prime} \mathrm{N}$ latitude and $44^{\circ} 29^{\prime}$ to $44^{\circ} 08^{\prime} \mathrm{E}$ longitude. Knowledge about climate, hydrology, soil and geology are given by $[9,12]$. Sites under study in Aquban consist of five shallows to medium depth (1, 2, 3, 4 and 5) found within mountain area contain different types of trees. In Sarkand village, six sites $(6,7,8,9,11$ and 14) along stream and seven springs $(10,12,13,15,16,17$ and 18) follow from mountain area then to stream flow. All the studied sites are about $40 \mathrm{Km}$ long (Figure 1) and (Table 1).

\subsection{Collection, preservation and identification of algae}

Algal samples were collected by plankton net for planktonic forms which pore size 25 micrometer and squeezing from leaves and stems of macrophytes plants. Then samples were preserved by using $1 \mathrm{ml}$ of lugal solution in air tight polylab vial sealed and labeling then brought to laboratory, Chlorophyceae and other algae concentrated by sedimentation and examined under microscope [13-18]. More details in this study carried under light microscope with camera and micrometer $(\mu \mathrm{m})$ were used to explain long 


\section{Al-Nahrain Journal of Science}

ANJS, Vol.24 (3), September, 2021, pp. 55-62

and wide for each species and photograph were taken and recorded species were checked by the last two check list[5, 6]. Identified various types of Algae as soon as possible to avoid loss of the taxonomic characters by light Microscope (Hund Wetzel S200) at 10X, 40X magnification. Water temperature was measured immediately in the field by placing a clean mercury thermometer $\left(0-60{ }^{\circ} \mathrm{C}\right)$ graduated up to $0.1{ }^{\circ} \mathrm{C}$ inside the water. EC \& $\mathrm{pH}$ were measured by using (pH-EC-TDS meter, HI 9812, Hanna instrument). Calcium, magnesium, nitrate, phosphate and sulfate were determined by [19]

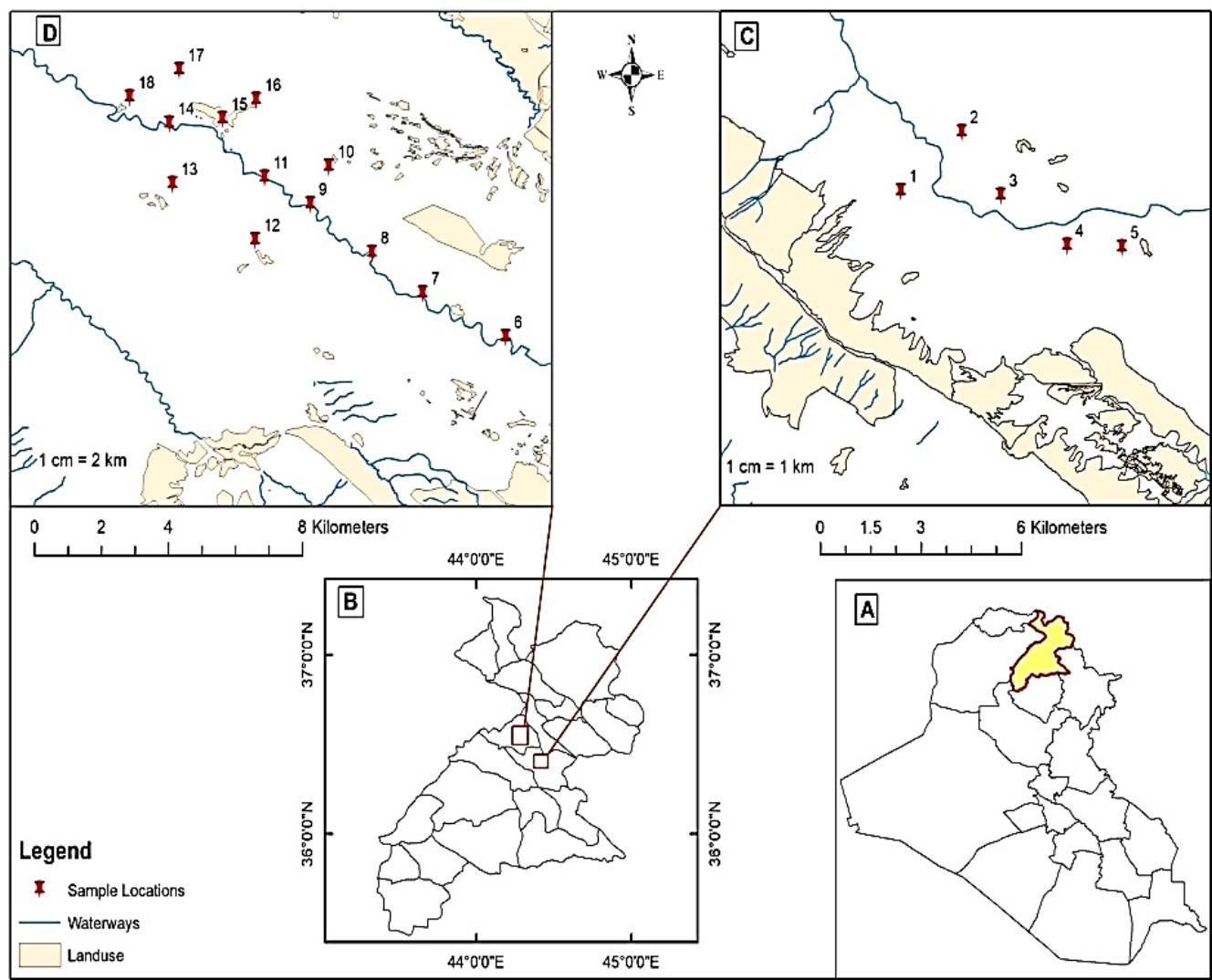

Figure 1. Show: (A) Map of Iraq and Erbil province shaded; (B) Map of Erbil governorate; (C) Aquban village;

(D) Sarkand Khaylaneyan village.

Table 1. Shows type and location of the studied area within Shaqlawa District

\begin{tabular}{|c|c|c|c|c|c|}
\hline Site & X-Field & Y-Field & Elevation & Location & Name of Village \\
\hline 1 & 447065.42 & 4024114.692 & $905 \mathrm{~m}$ & Sard Spring & \\
\hline 2 & 448620.345 & 4025272.842 & $902 \mathrm{~m}$ & Piawan Spring & \\
\hline 3 & 449343.633 & 4023623.880 & $887 \mathrm{~m}$ & Zhnan Spring & Aquban \\
\hline 4 & 450681.287 & 4022479.770 & $902 \mathrm{~m}$ & Darmanawa Spring & \\
\hline 5 & 452251.64 & 4022654.189 & $912 \mathrm{~m}$ & Mink Spring & \\
\hline 6 & 439655.001 & 4031776.001 & $736 \mathrm{~m}$ & Stream 1 & \\
\hline 7 & 437278.463 & 4033076.147 & $709 \mathrm{~m}$ & Stream 2 & \\
\hline 8 & 435814.981 & 4034419.117 & $707 \mathrm{~m}$ & Stream 3 & \\
\hline 9 & 434042.001 & 4035935.001 & $648 \mathrm{~m}$ & Stream 4 & \\
\hline 10 & 434707.036 & 4037048.419 & $713 \mathrm{~m}$ & Prenga Spring & \\
\hline 11 & 432436.724 & 4036853.074 & $669 \mathrm{~m}$ & Stream 5 & \\
\hline 12 & 432416.266 & 4034657.028 & $712 \mathrm{~m}$ & Nawkand Spring & Sarkand \\
\hline 13 & 429994.136 & 4036337.350 & $651 \mathrm{~m}$ & Chemma Spring & \\
\hline 14 & 430060.282 & 4038321.729 & $668 \mathrm{~m}$ & Stream 6 & \\
\hline 15 & 431498.957 & 4038387.875 & $743 \mathrm{~m}$ & Sarkand Spring & \\
\hline 16 & 432287.344 & 4039126.466 & $737 \mathrm{~m}$ & Benwan Spring & \\
\hline 17 & 430142.964 & 4039528.893 & $707 \mathrm{~m}$ & Azarian Spring & \\
\hline 18 & 428765.729 & 4039143.230 & $595 \mathrm{~m}$ & Razga Spring & \\
\hline
\end{tabular}




\section{Al-Nahrain Journal of Science}

ANJS, Vol.24 (3), September, 2021, pp. 55-62

\section{Results and Discussions}

Collected data on water temperature, pH, EC, salinity, calcium, magnesium, nitrate, phosphate and sulfate for each sample of water sites have been represented in Tables 2 and 3 . In the current study a total 11 new species records of Cyanophyta, Pyrrophyta, Xanthopyta and Cryptophyta species were identified from Shaqlawa district, within Erbil Province during September-2019 till August-2020 in Tables 4 and 5, these species are related to 10 genera belonging to 11 family, 8 order and 4 class, [5,6]. In this study Ophiocytium is considered the dominant new genera recorded with $18.1 \%$ followed by remaining others genera with $9.1 \%$ table 5. By accurate diagnostic and depending on new and scientific references we were able to determine new records species of algae not identified in Iraq so far and we will add them in the list of algal flora of Iraq and we will appear it as follows.

Three new records Cyanophyta reported in various sites in this study in summer and autumn seasons in along stream and springs and considered wide distributed because this may due to that blue-green algae are tolerance to bad or unsuitable environmental conditions [8]. Also the successful growth of Cyanophyta in current survey because possess different uses of metabolism[20]. Also it can in grow bright light condition and exhibit a wide range of diversity and can tolerate a wide range of temperature(22$32{ }^{\circ} \mathrm{C}$ ) [17]. Xanthopyta are much or less species-diverse than Cyanophyta with about 600 species and many of the 100 known genera and show wide range of form, species frequent in spring water in cold and warm water temperature and also in hard water[16]. This confirm with the results of this survey. Most of Pyrrophyta relatively little known of the ecology of fresh water, some species migrate vertically in water column during summer moving toward to light in day and to the bottom during night, also found in small water system and in pool was temporary, and some genera found or live in water is cold $<15{ }^{\circ} \mathrm{C}$, while most of the species are only recorded or thrive in summer when water temperature more than $15{ }^{\circ} \mathrm{C}$ [17], similar conclusions observed in the current study. About 200 Cryptophyta species have been described and it is likely that many more species still await formal description. About 100 known species occur in freshwater, also some occur smaller water bodies and rivers especially in the presence of lower temperatures[21]. Cryptomonas reflex identified in Sard spring in February-2021, this genus found in small water bodies and becomes more available in cold environment [17].

Table 2. Mean value of some water properties in study sites during the studied period.

\begin{tabular}{cccccccc}
\hline Site & $\begin{array}{c}\text { Place of } \\
\text { Collection name }\end{array}$ & $\begin{array}{c}\text { Habitat } \\
\text { type }\end{array}$ & $\begin{array}{c}\text { Air } \\
\text { Temperature }{ }^{\circ} \mathrm{C}\end{array}$ & $\begin{array}{c}\text { Water } \\
\text { Temperature }{ }^{\circ} \mathrm{C}\end{array}$ & $\mathrm{pH}$ & $\begin{array}{c}\text { EC } \\
\mu \text { s.cm }\end{array}$ & $\begin{array}{c}\text { Salinity } \\
\text { ppt }\end{array}$ \\
\hline 1 & Sard & Spring & 17.536 & 14.942 & 7.233 & 988.111 & 0.065 \\
2 & Piawan & Spring & 17.664 & 15.439 & 7.249 & 1124.778 & 0.056 \\
3 & Zhnan & Spring & 17.792 & 15.700 & 7.367 & 830.111 & 0.058 \\
4 & Darmanawa & Spring & 18.275 & 14.108 & 7.479 & 1611.667 & 0.052 \\
5 & Mink Spring & Spring & 18.211 & 14.039 & 7.764 & 627.472 & 0.059 \\
6 & Along Stream & Stream 1 & 20.583 & 16.211 & 7.844 & 786.250 & 0.072 \\
7 & Along Stream & Stream 2 & 21.333 & 17.517 & 7.875 & 785.222 & 0.071 \\
8 & Along Stream & Stream 3 & 21.892 & 17.381 & 7.894 & 782.972 & 0.076 \\
9 & Along Stream & Stream 4 & 22.200 & 17.272 & 7.992 & 764.056 & 0.078 \\
10 & Prenga & Spring & 22.364 & 18.231 & 7.401 & 810.639 & 0.059 \\
11 & Along Stream & Stream 5 & 21.483 & 17.397 & 7.823 & 841.778 & 0.077 \\
12 & Nawkand & Spring & 20.550 & 17.917 & 7.235 & 1392.583 & 0.110 \\
13 & Benwan & Spring & 20.633 & 18.475 & 7.309 & 1419.139 & 0.085 \\
14 & Along Stream & Stream 6 & 21.400 & 17.542 & 7.816 & 911.167 & 0.080 \\
15 & Sarkand & Spring & 21.133 & 18.033 & 7.330 & 924.972 & 0.059 \\
16 & Benwan & Spring & 21.942 & 18.169 & 7.372 & 975.639 & 0.055 \\
17 & Azarian & Spring & 22.317 & 16.108 & 7.297 & 2092.306 & 0.155 \\
18 & Razga & Spring & 23.067 & 16.628 & 7.817 & 989.222 & 0.084 \\
\hline
\end{tabular}




\section{Al-Nahrain Journal of Science}

ANJS, Vol.24 (3), September, 2021, pp. 55-62

Table 3. Mean value of some water properties in study sites during the studied period.

\begin{tabular}{cccccccc}
\hline \multirow{2}{*}{ Site } & $\begin{array}{c}\text { Place of } \\
\text { Collection name }\end{array}$ & $\begin{array}{c}\text { Habitat } \\
\text { type }\end{array}$ & $\mathrm{NO}_{3} \mathrm{mg} / \mathrm{L}$ & $\begin{array}{c}\mathrm{PO}_{4} \mu \mathrm{g} . \mathrm{P}- \\
\mathrm{PO}_{4} / \mathrm{L}\end{array}$ & $\mathrm{SO}_{4} \mathrm{mg} / \mathrm{L}$ & $\begin{array}{c}\text { Calcium } \\
\mathrm{mg} / \mathrm{L}\end{array}$ & $\begin{array}{c}\text { Magnesium } \\
\mathrm{Mg} / \mathrm{L}\end{array}$ \\
\hline 1 & Sard & Spring & 5.286 & 0.617 & 96.278 & 102.143 & 52.664 \\
2 & Piawan & Spring & 9.192 & 0.604 & 296.389 & 112.848 & 64.489 \\
3 & Zhnan & Spring & 15.197 & 0.706 & 132.333 & 89.819 & 42.591 \\
4 & Darmanawa & Spring & 5.078 & 0.868 & 353.889 & 257.005 & 72.586 \\
5 & Mink Spring & Spring & 7.167 & 0.740 & 110.944 & 73.920 & 50.442 \\
6 & Along Stream & Stream 1 & 11.611 & 1.503 & 102.667 & 72.171 & 46.704 \\
7 & Along Stream & Stream 2 & 12.458 & 1.627 & 113.111 & 68.199 & 50.601 \\
8 & Along Stream & Stream 3 & 12.894 & 1.354 & 107.333 & 70.012 & 47.719 \\
9 & Along Stream & Stream 4 & 11.336 & 1.199 & 131.056 & 71.195 & 49.098 \\
10 & Prenga & Spring & 38.008 & 0.974 & 71.028 & 73.737 & 53.105 \\
11 & Along Stream & Stream 5 & 13.497 & 1.226 & 120.639 & 71.323 & 50.825 \\
12 & Nawkand & Spring & 5.761 & 1.248 & 345.000 & 148.301 & 95.862 \\
13 & Benwan & Spring & 30.714 & 0.954 & 519.722 & 147.043 & 106.578 \\
14 & Along Stream & Stream 6 & 14.511 & 1.058 & 155.083 & 78.712 & 49.062 \\
15 & Sarkand & Spring & 38.614 & 1.054 & 172.222 & 98.945 & 50.722 \\
16 & Benwan & Spring & 39.025 & 1.126 & 239.722 & 91.624 & 53.590 \\
17 & Azarian & Spring & 1.986 & 0.957 & 978.306 & 294.848 & 80.455 \\
18 & Razga & Spring & 18.483 & 1.214 & 276.389 & 83.757 & 58.062 \\
\hline
\end{tabular}

Table 4. List of new Algal records species in the study sites during the studied period.

\begin{tabular}{|l|l|}
\hline Phylum: Cyanophyta (Cyanobacteria) & Tetraedriella Pascher 1930 \\
\hline Class: Cyanophyceae & 6-Tetraedriella polychloris Skuja 1964 \\
\hline Order: Chroococcales & Phylum: Cryptophyta (Cryptomonads) \\
\hline Family Entophysalidaceae & Class Cryptophyceae \\
\hline Marssoniella Lemmermann 1900 & Order Cryptomonadales \\
\hline 1-Marssoniella elegans Lemmermann 1900 & Family Cryptomonadaceae \\
\hline Order: Oscillatoriales & Cryptomonas Ehrenberg 1838 \\
\hline Family: Oscillatoriaceae & 7-Cryptomonas reflex Skuja 1868 \\
\hline Pseudoanabaena Lauterborn 1914 & Phylum: Pyrrophyta (Dinoflagellates) \\
\hline 2-Pseudoanabaena catenata Lauterborn 1914 & Class: Dinophyceae \\
\hline Family: Cyanothecaceae & Order: Gymnodiniales \\
\hline Cyanotheca (Naegeli) Komárek 1976 & Family: Tovelliaceae \\
\hline 3-Cyanotheca aeroginosa Komárek 1976 & Woloszynskia R.H.Thompson 1950 \\
\hline Phylum: Xanthopyta & 8-Woloszynskia tenuissima R.H.Thompson 1950 \\
\hline Class Xanthophyceae & Order: Peridiniales \\
\hline Order Mischococcales & Family: Peridiniaceae \\
\hline Family Characiopsidaceae & Peridinium Ehrenberg 1832 \\
\hline Characiopsis Borzi 1895 & 9-Peridinium goslaviense Woloszynska 1916 \\
\hline Family Ophiocytiaceae & Order: Phytodiniales \\
\hline Ophiocytium Naegeli 1849 & Family: Hemidiniaceae \\
\hline 4-Ophiocytium arbuscula Rebenhorst 1868 & Hemidinium F.Stein 1878 \\
\hline 5-Ophiocytium parvulum A.Braun 1855 & 10-Hemidinium naustum Stein 1883 \\
\hline Family Botryochloridaceae & Gymnodium Nygaard 1949 \\
\hline Order Goniochloridales & 11- Gymnodinium inversum Nygaard 1949 \\
\hline Family Goniochloridaceae & \\
\hline
\end{tabular}




\section{Al-Nahrain Journal of Science}

ANJS, Vol.24 (3), September, 2021, pp. 55-62

\begin{tabular}{|c|c|c|c|c|c|c|}
\hline & Name of Algal species & Genera & Species & $\%$ & Number of New species & $\%$ \\
\hline & $\begin{array}{l}\text { Phylum: Cyanophyta } \\
\text { Class: Cyanophyceae }\end{array}$ & & & & & \\
\hline 1 & Marssoniella Lemmermann 1900 & 1 & 1 & 7.7 & 1 & 9.1 \\
\hline 2 & Pseudoanabaena Lauterborn 1914 & 1 & 1 & 7.7 & 1 & 9.1 \\
\hline 3 & $\begin{array}{l}\text { Cyanotheca (Naegeli) Komárek } 1976 \\
\text { Phylum: Xanthopyta } \\
\text { Class Xanthophyceae }\end{array}$ & 1 & 1 & 7.7 & 1 & 9.1 \\
\hline 4 & Ophiocytium Naegeli 1849 & 1 & 4 & 30.7 & 2 & 18.1 \\
\hline 5 & $\begin{array}{l}\text { Tetraedriella } \text { Pascher } 1930 \\
\text { Phylum: Cryptophyta } \\
\text { Class Cryptophyceae }\end{array}$ & 1 & 1 & 7.7 & 1 & 9.1 \\
\hline 6 & $\begin{array}{l}\text { Cryptomonas Ehrenberg } 1838 \\
\text { Phylum: Pyrrophyta } \\
\text { Class: Dinophyceae }\end{array}$ & 1 & 1 & 7.7 & 1 & 9.1 \\
\hline 7 & Woloszynskia R.H.Thompson 1950 & 1 & 1 & 7.7 & 1 & 9.1 \\
\hline 8 & Peridinium Ehrenberg 1832 & 1 & 1 & 7.7 & 1 & 9.1 \\
\hline 9 & Hemidinium F.Stein 1878 & 1 & 1 & 7.7 & 1 & 9.1 \\
\hline 10 & $\begin{array}{l}\text { Gymnodium Nygaard } 1949 \\
\text { Total }\end{array}$ & $\begin{array}{c}1 \\
10\end{array}$ & $\begin{array}{c}1 \\
13\end{array}$ & $\begin{array}{c}7.7 \\
100\end{array}$ & $\begin{array}{c}1 \\
11\end{array}$ & $\begin{array}{l}9.1 \\
100\end{array}$ \\
\hline
\end{tabular}

Descriptions new records

Marssoniella elegans Lemmermann 1900 (Pl.1, Figure 1): Cells $1.3-5 \mu \mathrm{m}$ width, $4-6 \mu \mathrm{m}$ length at $40 \mathrm{X}$ magnification, colony comprise or content $8-12$ pyriform to oval cell, arrangement is radiate (P.471, Pl.107, Figure 12) [15]. Found in along stream at site 7 during September-2019. Pseudanabaena catenata Lauterborn 1914 (PI.1, Figure 2): Cells $1.8-2.2 \mu \mathrm{m}$ width and $2-5 \mu \mathrm{m}$ length at $40 \mathrm{X}$ magnification, single trichome, not observed any attenuated towards both ends, narrowed cross-wall, appeared rectangular from side viewed, not found any gas vacuoles. (P.84, Pl.13A) [16]. Recorded in Darmanawa spring during August-2020.

Cyanotheca aeroginosa Komárek 1976 (PI.1, Figure 3): Cells $10-30 \mu \mathrm{m}$ width and $10-45 \mu \mathrm{m}$ length at $40 \mathrm{X}$ magnification, large cells, solitary live, ovoid to elliptical shaped, color of cell blue-green or olive green and is bright, movement is slightly. (P.214, Figure 4.32) [22]. Found in Nawkand spring during July-2020.

Ophiocytium arbuscula (A.Braun) Rebenhorst 1868(PI.1, Figure 4): Cell attached or connected by short stalk, form colony comprise a cylindrical cell, slightly straight or curved, $2-5 \mu \mathrm{m}$ width, up to $60 \mu \mathrm{m}$ length at $40 \mathrm{X}$ magnification, attached by stalk. (P.258, Pl.70A) [16]. Recorded in Azarian spring during February-2020.

Ophiocytium parvulum (Perty) A. Braun 1855 (Pl.1, Figure 5): Cells 3-9 $\mu \mathrm{m}$ width and up to $500 \mu \mathrm{m}$ length at 40X magnification. Cylindrical cells curved or may be straight, spines absent and rounded apices, one swollen than others. (P.258, P1.70B) [16]. Found in Benwan spring during February-2020

Tetraedriella polychloris Skuja (Pl.1, Figure 6): Cells 20$42 \mu \mathrm{m}$ width at $40 \mathrm{X}$ magnification, tetrahedral, central body is small, chloroplast tended, oil droplet present [16] (P.259, Pl.66D). Found in Darmanawa spring during August-2020.
Cryptomonas reflex Skuja 1868 (PI.2, Figure 1): Cells 12$16 \mu \mathrm{m}$ width, 27-37 $\mu \mathrm{m}$ length at 40X magnification, ovoid broadly to ellipsoidal to spindle form, curve at anterior end, pointed at posterior end, chromatophore parietal and elongateP.58, Figure 40) [23]. Recorded in Sard spring during February-2020.

Woloszynskia tenuissima R.H.Thompson 1950 (Pl.2, Figure 2): Cells $32-36 \mu \mathrm{m}$ width and 32-40 $\mu \mathrm{m}$ length at $40 \mathrm{X}$ magnification. Cells is quadrate form in ventral view and flattened at dorsiventrally, concave form in ventrally and curved laterally, short point at apex and pointed or found a deep furrow in antapex. Hypocone slightly shorter than epicone, dividing by cingulum. Chloroplast ovoid or irregular, yellow brown to yellow in colour. (P.198, Pl. L, M) [16]. Recorded in Darmanawa spring during August2020.

Peridinium goslaviense Woloszynska 1916 (Pl.2, Figure 3): Cells 11-22 $\mu \mathrm{m}$ width and 12-24 $\mu \mathrm{m}$ length at $40 \mathrm{X}$ magnification. Ovoid and elongated cells, flattened at dorsiventrally but weakly, epivalve pointed with pore apical, hypovalve have circle but half and spines found (P. 9070, Pl.10) [24]. Recorded in along stream at site 8 during August-2020.

Hemidinium naustum Stein 1883 (PI.2, Figure 4): Cells $14-30 \mu \mathrm{m}$ width and $22-36 \mu \mathrm{m}$ length at $40 \mathrm{X}$ magnification, cell elliptical to round in ventral view, flattened dorsoventrally, cingulum started from ventral to left side, Chloroplast many and colors changed yellow brown to brown. (P.207, P1.52K-M) [16]. Found along stream at site 9 during August-2020.

Gymnodinium inversum Nygaard 1949 (Pl.2, Figure 5): Cell 16-26 $\mu \mathrm{m}$ width, 20-30 $\mu \mathrm{m}$ length at $40 \mathrm{X}$ magnification, elongated and ellipsoidal form, compressed dorsiventrally, rounded and broadly at both apexes, epicone slightly smaller than Hypocone, extend of sulcus of length of hypocone and epicone. (P.191, Pl.47, Figures E,F) [16]. Observed in the Nawkand spring through October-2020. 


\section{Al-Nahrain Journal of Science}

ANJS, Vol.24 (3), September, 2021, pp. 55-62
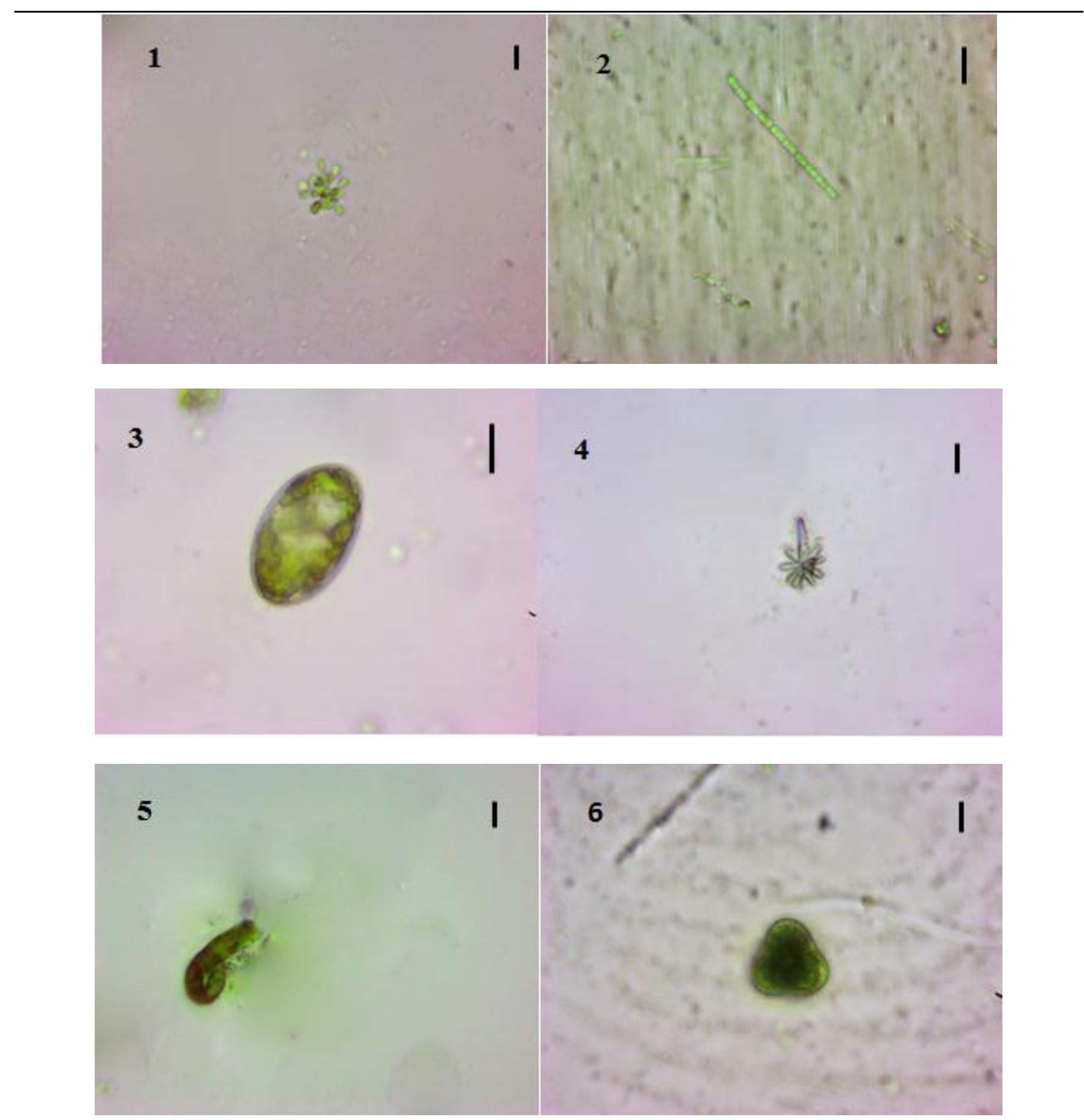

Plate 1. Photomicrographs of Algae species recorded in the study area: 1. Marssoniella elegans 2. Pseudanabaena catenata,

3. Cyanotheca aeroginosa, 4. Ophiocytium arbuscula, 5. Ophiocytium parvulum, 6. Tetraedriella polychloris Skuja Scale bar $=10 \mu \mathrm{m}$. 


\section{Al-Nahrain Journal of Science}

ANJS, Vol.24 (3), September, 2021, pp. 55-62
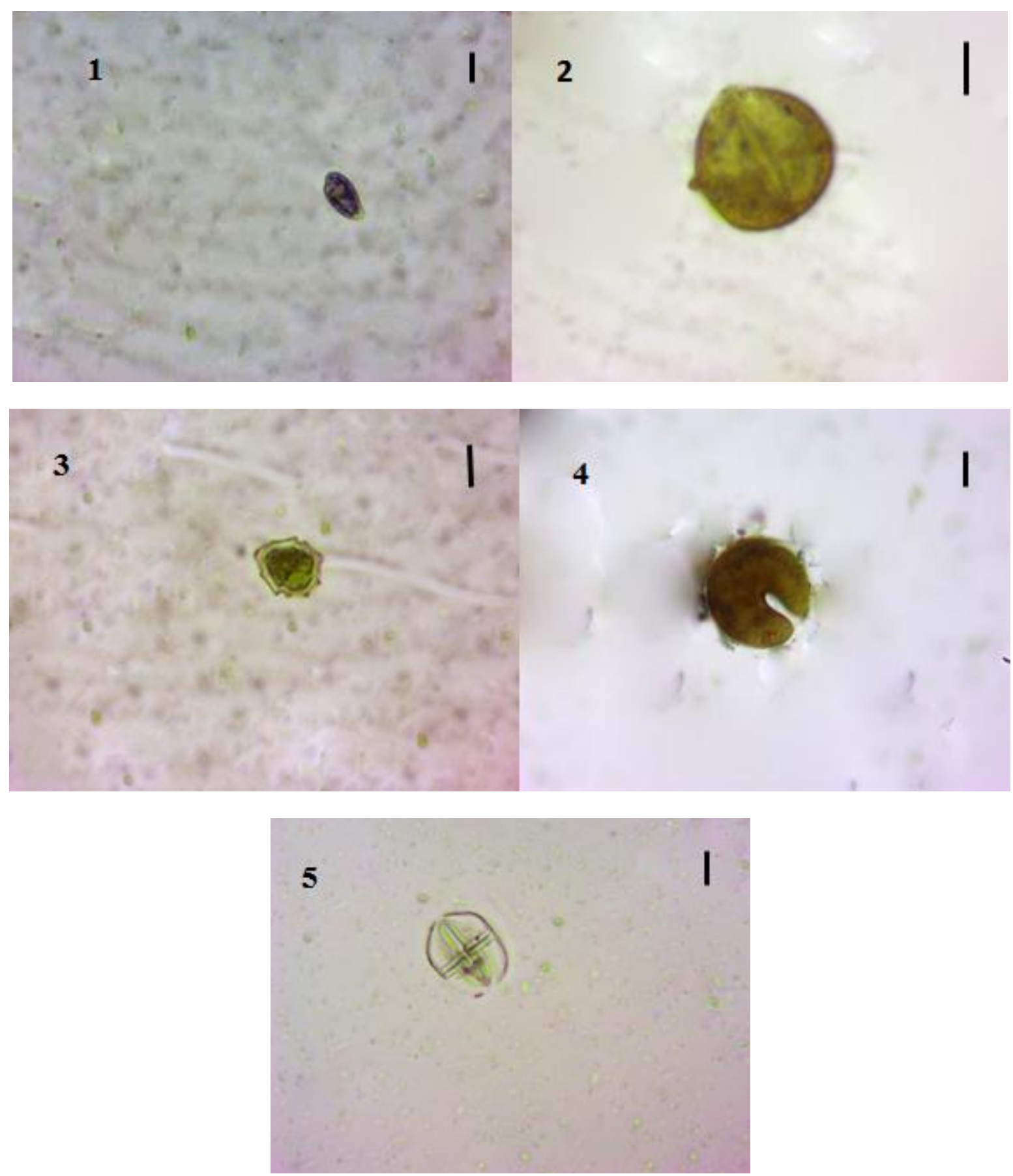

Plate 2. Photomicrographs of Algae species recorded in the study area: 1. Cryptomonas reflex, 2. Woloszynskia tenuissima, 3. Peridinium goslaviense, 4. Hemidinium naustum, 5. Gymnodinium inversum Scale bar $=10 \mu \mathrm{m}$.

\section{Conclusions}

From the results of the current study, it is clear that the found of phytoplankton, reflected quality of Shaqlawa water resources, and this area is favorable for living others types of organisms. New algal species reported in this survey were not recorded in the all Iraqi area, 16 new algal species belonging to Cyanophyta, Xanthopyta, Cryptophyta Ascomycota were identified.

\section{References}

[1] Ali H. A.; Al-Hussieny A. A. and Owaid M. N.; "New seven records of Euphrates River algae in Iraq". Songklanakarin J. Sci. Technol, 43(1), 181-187, 2021. 


\section{Al-Nahrain Journal of Science}

ANJS, Vol.24 (3), September, 2021, pp. 55-62

[2] Selvarajan R. E.; Felföldi T. M.; Tauber T. J.; Sanniyasi E. M.; Sibanda M. T. and Tekere K. M.; "Screening and Evaluation of Some Green Algal Strains (Chlorophyceae) Isolated from Freshwater and Soda Lakes for Biofuel Production". Energies, 8, 7502-7521, 2015.

[3] Abdulkareem P. M. and Anwer S. S.; "Uptake of different dyes by two new strains of microalgal dyr biomass " Iraqi J of Agricultural Sciences, 52(1), 48-62, 2021.

[4] Aziz F. H.; Bapeer U. H. K. and Najmadden S. K.; "Fourteen algae new records reported in five artificial ponds in the main parks within Erbil city, Kurdistan region, Iraq". Mesopotamia Environmental Journal, 4(1), 12-22, 2017.

[5] Aziz F. H.; "Checklist of the Algae in Iraqi Kurdistan Region". Zanco J. of Pure Applied Science. Salahaddin University, 23(3), 31-72, 2011.

[6] Maulood B. K.; Hassan F. M.; Al-Lami A. A. A.; Toma J. J. and Ismail A. M.; "Checklist of Algal Flora in Iraq.". Republic of Iraq, Baghdad, Ministry of Environment, 93pp, 2013.

[7] Aziz F. H. and Muhammad A. Q. A.; "Twenty new Records of Algae in Some Springs around Safeen Mountain Area". Journal of Advanced Laboratory Research in Biology,7(3), 17-23, 2016.

[8] Aziz F. H. and Rasoul B. H.; "Thity two Algal new records reported in Ponds at Gwer Sub-District, ErbilKurdistan Region of Iraq". Bull. Iraq nat. Hist. Mus.; 14(1), 27-42, 2016.

[9] Aziz F. H. and Yasin S. A.; "Twenty- five new records of algae in eight artificial fish ponds in Erbil". ZANCO Journal of Pure and Applied Sciences, 31(4), 153-166. 2019.

[10] Al-Hussieny A. A.; "Recording New Species of Algae in Baghdad Environment within the Tigris River, Iraq". Haya: The Saudi Journal of Life Sciences, 2(7), 243-247, 2017.

[11] Al-Hussieny A. A.; "Recording of new Algal species within the Euphrates River Environment in Iraq" International Journal of Science and Nature, 8 (4), 16, 2017.

[12] Aziz F. H.; Hassan F. M.; and Rasul B. H.; "An Ecological Observation on Inland water Ecosystem in Erbil -Iraq Kurdistan with particular reference to blue green algae". Baghdad Science Journal, 11(3),13801387, 2014.

[13] Desikachary T. V.; "Cyanophyta". Academic Press, New York, London, Indian Council of Agricultural Research, New Delhi, 685pp, 1958.

[14] Prescott G. W.; "How to Knoe Freshwater Algae". William C Brown CO Publishers. Dubuque, Lowa, 275pp, 1968.

[15] Prescott G. W.; "Algae of the Western Great Lakes Area. 6th Edition". William C Brown CO Publishers. Dubuque, Lowa, 980pp, 1970.
[16] John D. M.; Whitton B. A.; and Brook A. J.; "The Freshwater Algal Flora of the British Isles: An Identification Guide to Freshwater and Trrestrial Algae". Published by the Press Syndicate of the University of Cambridge, United Kingdom, 702pp, 2002.

[17] John D. M.; Braid R. B.; and Brook A. J.; "The Freshwater Algal Flora of the British Isles: An Identification Guide to Freshwater and Trrestrial Algae. $2^{\text {nd }}$ Edition". Published by the Press Syndicate of the University of Cambridge, United Kingdom, 920pp, 2011.

[18] Wehr J. D.; Sheath R. G.; and Kociolek J. P.; "Freshwater Algae of North America: Ecology and Classification." Academic Press in an import of Elsevier Inc, 1050pp, 2015.

[19] Bartram J. and Ballance R.; "Water Quality Monitoring - A Practical Guide to the Design and Implementation of Freshwater Quality Studies and Monitoring Programmes". Published on behalf of United Nations Environment Programme and the World Health Organization, 534pp, 1996.

[20] Hamadamen A. R.; "Eco-Phycological study of the Qandil mountain streams/Sulaimani". M.Sc. Thesis. University of Salahaddin-Erbil, 194pp, 2015.

[21] Sevindik T. O.; "Phytoplankton Composition of Çaygören Reservoir, Balikesir-Turkey". Turkish Journal of Fisheries and Aquatic Sciences, 10, 295304, 2010.

[22] Matthews R. A.; "Algae in Northwest Washington Lakes Volume1 Cyanobacteria". Published by Creative Commons Attribtion Non-Commercial No Derivatives International License, 273pp, 2012.

[23] M. Khonder et al.; "New Records of phytoplankton for Nangladesh.2. Cryptophyceae and synurophyceae". Bangladesh J. Bot.; 36(1), 53-59, 2007.

[24] Alwaeli A. A. A. and Athbi A. M.; "New Records of Ten Species of phytoplankton from the Shatt al Arab River, South of Iraq". J of Annals of R.S.C.B, 25(6), 9061-9073, 2021. 